\section{Effects of a hydroalcoholic extract of Turnera diffusa in tests for adaptogenic activity}

\author{
Andréia G. Bezerra, Fúlvio R. Mendes, "Ricardo Tabach, Elisaldo \\ A. Carlini
}

Departamento de Psicobiologia, Universidade Federal de São Paulo, Brazil.

\begin{abstract}
The objective of the present study was to assess whether Turnera diffusa Willd. ex Schult., Turneraceae, (TD), plant known in popular medicine as tonic and aphrodisiac, has other effects that are characteristic of an adaptogen substance, such as improvement of the memory and reduction of the damage caused by stress. We carried out an initial screening to detect a possible toxicity of the plant. In that phase of the study we used tests of observational screening; evaluation of acute toxicity; measurement of motor activity and motor coordination, and sleeping time induced by pentobarbital, and observed that the extract presented low toxicity and no stimulant or depressant effect on the animals. We then performed specific tests for the evaluation of an adaptogen effect. TD did not protect the stomach of the animals from the formation of ulcers, neither did it alter the plasmatic levels of adrenocorticotropic hormone (ACTH) and corticosterone of the animals submitted to immobilization and cold. As regards the evaluation of memory in passive avoidance, TD did not inhibit scopolamine-induced amnesia. Additionally, the hydroalcoholic extract presented low antioxidant activity in vitro. In the models used, TD produced no changes in relation to a possible adaptogen effect.
\end{abstract}

Revista Brasileira de Farmacognosia Brazilian Journal of Pharmacognosy 21(1): 121-127, Jan./Feb. 2011

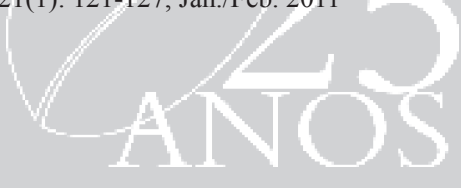

Article

Received 12 Mar 2010

Accepted 7 Jul 2010

Available online 25 Feb 2011

Keywords:

Turnera diffusa

adaptogens

toxicity

stress

memory

antioxidant

ISSN 0102-695X

doi: 10.1590/S0102-695X2011005000019

\section{Introduction}

Turnera diffusa Willd. ex Schult. (syn. Turnera aphrodisiaca Ward.), Turneraceae, popularly known in Brazil as damiana, is famous worldwide as tonic and aphrodisiac. The Missouri Botanical Garden recently reclassified the Turnera genus as part of Passifloraceae family (Tropicos.org, 2010). However, this change is not consensus among botanists and we decided maintain the name Turneraceae in the present paper, according to the list of species of "Flora do Brasil" (Arbo, 2010).

The popular use of Turnera diffusa (TD) leaves dates back to ancient times. There are reports according to which it has been used as a sexual stimulant in the United States since the 19th century (Russo, 2001). In Brazil, the plant is used as tonic, aphrodisiac, against neurasthenia and in recovery of convalescent states (Mendes \& Carlini, 2007). In addition to those uses related to a possible adaptogen effect, it is also used popularly as digestive; anti-ulcer; hypoglycemiant; diuretic; anti-malaria; to treat diarrhea; against alcoholism; as an appetite stimulant, among other uses (Corrêa, 1984; Miller, 1993; Mors et al., 2000; Carlini et al., 2006).

In spite of the wide range of applications and popular uses of the plant, few are the scientific studies that evaluate its pharmacological properties. Alarcon-Aguilar et al. (1998) observed a reduction of the hyperglycemia peak induced by a subcutaneous injection of glucose in rabbits treated with the hydroalcoholic extract of TD. This possible hypoglycemiant effect was not confirmed in a later study using mice with aloxane-induced diabetes (Alarcon-Aguilar et al., 2002). The ethanolic and dichloromethanic extracts, on the other hand, were effective in reducing the ulcerations induced in mice by chloridric acid ( $\mathrm{HCl})$ and ethanol (Gracioso et al., 2000). Kumar \& Sharma $(2005 ; 2006)$ evaluated mice that received the methanolic extract of $\mathrm{TD}$, its fractions and isolated constituents as regards their performance in the elevated plus maze, and observed an effect similar to that of diazepam, attributing this possible anxyolitic effect to apigenin.

Its possible aphrodisiac effect, undoubtedly the main popular use of TD, was also a target of pharmacological investigation. The fluid hydroalcoholic extracts of TD and Pfaffia paniculata Kuntze, separately or in combination, were administered to rats that did not meet the criteria of sexual vigor, and they improved the copulation performance of those animals (Arletti et al., 1999). In another study, animals that were in the phase of sexual exhaustion had a faster recovery of their copulation behavior after receiving the TD extract (Estrada-Reyes et al., 2009).

Considering those findings, which seem to corroborate some of the popular indications of TD, the 
objective of this work was to evaluate the effects of the plant in animal models and biochemical indicators of an adaptogen action that is, as tonic, anti-stress and for memory.

\section{Material and Methods}

\section{Drugs and botanical material}

The supplier Quimer Ltda. provided aerial parts of TD (leaves and flowered branches) of Mexican origin. The botanical identity was confirmed by pharmacognostic analysis and the material deposited at Herboteca Carlos Stelfelld (UFPR), No. 340. We used sodium pentobarbital, scopolamine and thiobarbituric acid (TBA) by Sigma, trichloroacetic acid (TCA) by Merck, ethylic alcohol and salts - sodium chloride, sodium phosphate monobasic and sodium phosphate dibasic (used for the preparation of the phosphate buffer) - by Synth, Brazil.

\section{Preparation of the extract}

After being ground, each $100 \mathrm{~g}$ of TD powder were left in maceration in $1000 \mathrm{~mL}$ of hydroalcoholic solution $(50 \%)$. We chose the turbolise technique (Franco, 1990), using a semi-industrial blender. The extract was concentrated on rotavap (Fisaton) after which it was frozen-dried (Edward Pirani device) for us to obtain the dry extract. The yield of dry extract was $13 \%$.

\section{Animals}

We used male and female Swiss albino mice $(30-50 \mathrm{~g})$ and male Wistar rats $(300-400 \mathrm{~g}), 3$ to 4 months old in the beginning of the experiment. The animals were from the biotery of the Department of Psychobiology of Unifesp. They were housed in rooms with controlled temperature $\left(23 \pm 2{ }^{\circ} \mathrm{C}\right)$ and a light/dark cycle of 12 $\mathrm{h}$, with water and food ad libitum. At the end of the experiment, the animals were euthanized in $\mathrm{CO}_{2}$ chamber or decapitated. The Committee of Ethics in Research of UNIFESP approved the protocol (Process 0178/04).

\section{Preliminary tests}

\section{Observational screening}

We used six mice for each extract dose. The animals received intraperitoneal (i.p.) administrations of water (control) or extract at the doses of 1, 10 and $100 \mathrm{mg} / \mathrm{kg}$. For the oral administration (gavage) we used water (control) or extract at the doses of 10,100 and 1000 $\mathrm{mg} / \mathrm{kg}$. We observed the behavior of the animals $5,10,15$, $30,60,120,180,240 \mathrm{~min}$ and $24 \mathrm{~h}$ after administration, recording the presence or absence of the following signs: miction, defecation, writhing, bristling fur, palpebral ptosis, locomotor activity, muscular tonus, tremors or seizures, ataxia, stereotypy, gnawing, grooming, lacrimal secretion and exophthalmia (Mattei et al., 1998). The animals were killed after $24 \mathrm{~h}$ and the general appearance of the liver, kidney, and intestines was compared with that of the controls. The data were analyzed qualitatively and used to establish the doses for subsequent tests.

\section{Evaluation of acute toxicity}

The acute toxicity was evaluated through the administration of high doses of TD extract $(2 \mathrm{~g} / \mathrm{kg}$, i.p. and $5 \mathrm{~g} / \mathrm{kg}$, p.o.) to male and female mice (five of each sex). We employed the highest doses suggested by Hodgson \& Levi (2000) to estimate the toxicity. The animals were observed for 14 days, being evaluated as regards their weight, general aspect, time and number of deaths, when it was the case (Carlini et al., 1986).

\section{Measurement of motor activity}

The equipment consists of a transparent acrylic box with photoelectric cells and a device to count ambulation. The ten mice we used in each group received water orally (control) or TD extract at the doses of 200 and $1000 \mathrm{mg} / \mathrm{kg}$ (these doses were chosen considering the results of the observational screening). After five min of habituation in the boxes, the animals received the injections and were placed back in the boxes, having their movement computed 15, 30, 60, 90 and 120 min later, in a cumulative count (Mendes et al., 2002).

\section{Measure of motor coordination (rota-rod)}

The equipment consists of a rotational bar with three cm of diameter, divided into five equal compartments. The system is placed $40 \mathrm{~cm}$ above the counter and moves at $12 \mathrm{rpm}$ (Pires et al., 2009). The animals were selected one day before the test, and only those that remained on the rotational bar for $60 \mathrm{~s}$ in at least one out of three attempts were selected. Three groups with ten mice each received oral administrations of water (control) or TD extract at the doses of 200 and $1000 \mathrm{mg} / \mathrm{kg}$. They were evaluated before the administration of the extract (basal) and 30, 60 and $120 \mathrm{~min}$ after it. Their time on the rod was recorded up to a maximum of $60 \mathrm{~s}$.

Potentialization of pentobarbital-induced sleep

Three groups with ten mice each received oral administrations of water (control) or TD extract at the doses of 200 and $1000 \mathrm{mg} / \mathrm{kg}$. One hour later they received an intraperitoneal administration of $50 \mathrm{mg} / \mathrm{kg}$ of sodium pentobarbital. We then registered their sleep 
latency and total sleeping time (interval between the loss and the recovery of the rearing reflex) (Carlini et al., 1986).

\section{Specific tests for the evaluation of the adaptogen action}

Stress by immobilization and cold

We used three groups of ten rats each, treated orally for seven days with either TD extract at the doses of 200 and $1000 \mathrm{mg} / \mathrm{kg}$ or with water (control group), being the last dose one hour before immobilization.

The animals were placed in wire cages (three per cage) and deprived of food and water $24 \mathrm{~h}$ before the test. Each animal was immobilized with wire screen and then placed in a cold chamber at approximately 10 ${ }^{\circ} \mathrm{C}$ for $2 \mathrm{~h}$. After this period, the animal was euthanized by decapitation and had its stomach removed for the evaluation of the degree and index of ulceration according to Mendes et al. (2007).

The thymus and adrenal glands were removed, dissected and weighed in an analytical scale soon after the animals were euthanized. The value obtained for the weight of the tissues was corrected according to the weight of the animals by means of the formula: $\mathrm{W}=(\mathrm{Ax} 100) / \mathrm{T}$, where $\mathrm{W}$ is the proportional weight, $\mathrm{A}$ is the absolute weight of the thymus or adrenal glands and $\mathrm{T}$ is the total weight of each animal.

\section{Plasmatic measurement of ACTH and corticosterone}

The blood of the animals submitted to immobilization and cold was collected in test tubes, in the presence of anticoagulant EDTA, immediately after decapitation. The levels of corticosterone were analyzed through the double antibody RIA method, specific for rats and mice. We used a commercial kit for that purpose (ICN Biomedicals, USA). ACTH was measured in a chemical analysis laboratory (using DPC Immulite ACTH, Los Angeles, CA), by chemiluminescence (Palma et al., 2000). Data of non-stressed rats from our previous studies were used as reference of basal level of corticosterone and ACTH (Mendes et al., 2007).

Evaluation of memory - passive avoidance test

Groups with ten mice each received water or extract orally at the doses of 100 and $500 \mathrm{mg} / \mathrm{kg}$ for 43 consecutive days, the last dose being administered one hour before the administration of scopolamine $(0.5 \mathrm{mg} /$ $\mathrm{kg}$, i.p.).

The task of passive avoidance was evaluated in a device with two compartments, one light and the other dark, and a wire grid floor (Marques et al., 2004). On the day of the training, the animals received scopolamine or saline (negative control). Thirty min later we placed them individually in the light compartment and recorded the time they spent to move to the dark compartment (latency of acquisition). On passing to the dark side, the animal received three shocks of $0.5 \mathrm{~mA}$ and $1 \mathrm{~s}$ of duration on its paws at intervals of $30 \mathrm{~s}$. After $24 \mathrm{~h}$, the animals were again placed in the light compartment, and we recorded the time they took to cross to the dark side (latency of retention), up to a maximum of $180 \mathrm{~s}$.

\section{Evaluation of the in vitro antioxidant capacity}

The in vitro antioxidant activity was evaluated by the measurement of the lipoperoxidation of brain homogenate of the rats in the presence of different concentrations of TD extract. The supernatant, extracted from the homogenate after 15 min of centrifugation at $3000 \mathrm{rpm}$ and $4{ }^{\circ} \mathrm{C}$, was diluted with a phosphate buffer. After that, $50 \mu \mathrm{L}$ of each concentration of TD solution were pipetted (in duplicate) in erlenmeyers flasks containing $3 \mathrm{~mL}$ of homogenate and half of them (one of each concentration) was incubated in water-bath at $37^{\circ} \mathrm{C}$ for $60 \mathrm{~min}$, while the rest remained at room temperature.

After $60 \mathrm{~min}$, all the flasks (incubated or not) received $1 \mathrm{~mL}$ of trichloride acetic acid and were centrifuged at $3000 \mathrm{rpm}$, for $15 \mathrm{~min}$, at $4{ }^{\circ} \mathrm{C}$, after which $1 \mathrm{~mL}$ of the supernatant of each sample was pipetted into a test tube containing $1 \mathrm{~mL}$ of thiobarbituric acid (TBA). The tubes were boiled for $20 \mathrm{~min}$ and then placed in ice. Malondialdehyde (MDA), one of the products of the spontaneous lipoperoxidation, reacts with TBA, forming a colored compound whose intensity was measured by a spectrophotometer at $535 \mathrm{~nm}$ (Stocks et al., 1974). The mean of percentage of inhibition was obtained for each extract concentration in four assays. This mean was used for us to calculate the $Q_{1 / 2}$ (concentration that inhibits $50 \%$ of the peroxidation) by linear regression.

\section{Statistical analysis}

The results are presented as mean \pm standard error (SE). The level of significance was set at $p<0.05$. We used the following tests: i) ANOVA followed by Duncan, when necessary, for the tests of motor activity; potentialization of pentobarbital-induced sleep; evaluation of the degree and index of ulceration; weight of the thymus and adrenal glands; measurement of ACTH and corticosterone; ii) KRUSKAL-WALLIS followed by Mann-Whitney, when necessary, for the passive avoidance and rota-rod tests.

\section{Results}

Preliminary tests 


\section{Observational screening}

The animals showed a good tolerability to TD doses in the range 1 to $100 \mathrm{mg} / \mathrm{kg}$ (i.p.) or 10 to $1000 \mathrm{mg} /$ $\mathrm{kg}$ (p.o.). There was a slight increase in the motor activity in the mice treated orally at the doses of 100 and $1000 \mathrm{mg} /$ $\mathrm{kg}$, after about $40 \mathrm{~min}$ of treatment. On the other hand, the animals presented ptosis, abdominal contortions and reduction of the motor activity when the doses of 10 and $100 \mathrm{mg} / \mathrm{kg}$ were administered intraperitoneally. None of the animals had died after $24 \mathrm{~h}$, and the macroscopic analysis of the organs (liver and kidney) did not show alterations when compared with the control group (data not shown).

\section{Evaluation of acute toxicity}

The administration of TD extract at the dose of $2 \mathrm{~g} / \mathrm{kg}$ (i.p.) resulted in the death of six animals (four males and two females), being three on the first day, two on the second and one on the third. The oral dose of 5 $\mathrm{g} / \mathrm{kg}$, on the other hand, led to neither death nor visible signs of toxicity over the 14 days of observation (data not shown).

\section{Measurement of motor activity}

The oral administration of TD (200 and $1000 \mathrm{mg} /$ $\mathrm{kg}$ ) did not alter the locomotor activity of the mice when compared with the ones in the control group (Figure 1).

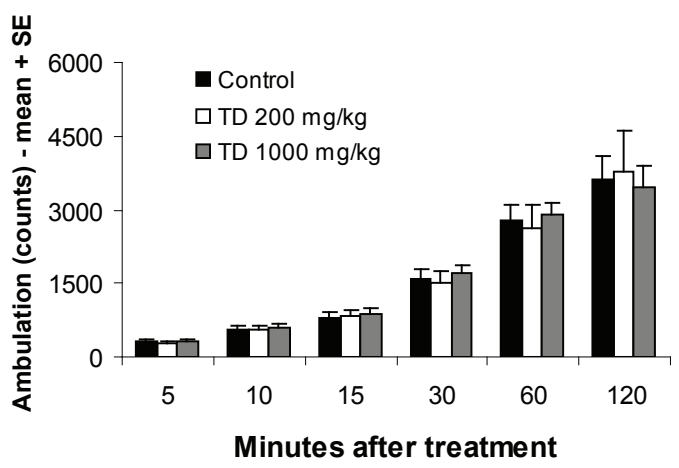

Figure 1. Locomotor activity of the mice treated acutely with Turnera diffusa extract (TD) at the doses of 200 and $1000 \mathrm{mg} / \mathrm{kg}$. The columns and bars represent the means+SE. ANOVA, n.s.

\section{Measurement of motor coordination (rota-rod)}

The oral administration of TD extract (200 and $1000 \mathrm{mg} / \mathrm{kg}$ ) did not alter the motor coordination of the mice on the rota-rod when compared with the control group (data not shown).
Effect on the time of pentobarbital-induced sleep

There was no difference regarding the latency of sleep onset and the total sleeping time between the mice in the control group and the mice that received TD extract (data not shown).

\section{Specific tests for the evaluation of the adaptogen action}

Stress by immobilization and cold

The results showed that the oral administration of TD extract did not protect the rats from the development of gastric ulcers caused by stress (Table 1). The group treated with the dose of $1000 \mathrm{mg} / \mathrm{kg}$ presented increase in the weight of the adrenal glands when submitted to immobilization and cold (Table 1), but no differences in the weight of the thymus.

Plasmatic measurement of ACTH and corticosterone

The oral administration of 200 and $1000 \mathrm{mg} / \mathrm{kg}$ of TD did not cause differences in the plasmatic levels of ACTH and corticosterone of the animals submitted to stress by immobilization and cold (Table 1).

Evaluation of memory - Passive avoidance

Figure 2 shows that scopolamine $(0.5 \mathrm{mg} /$ $\mathrm{kg}$ ) injected intraperitoneally was effective in inducing amnesia in the mice (comparison with the saline+saline group). However, the animals treated with chronic oral administrations of TD extract (100 and $500 \mathrm{mg} / \mathrm{kg}$ ) presented similar latency of retention in the passive avoidance to that of the control group (scopolamine), that is, the treatment with TD extract did not reverse the damage caused by the amnesic drug.

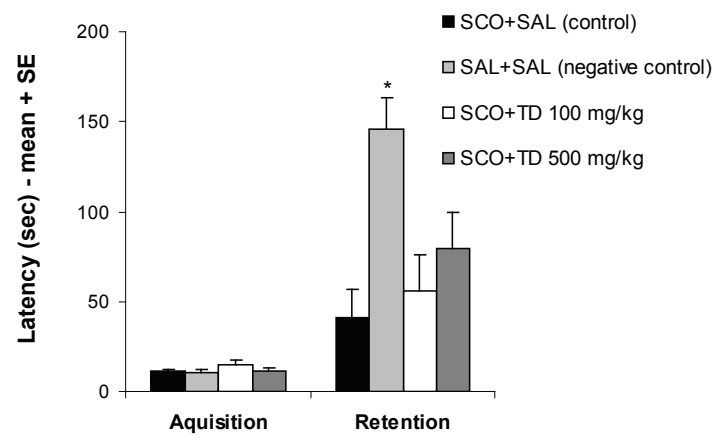

Figure 2. Effect of the treatment with Turnera diffusa extract (TD) on the amnesia caused by scopolamine (SCO) in mice on the passive avoidance test. SAL: saline. The columns and bars represent, respectively, the means $+\mathrm{SE}$ of the latency for the animals to cross the door. ${ }^{*} p<0.05$, Kruskal-Wallis/MannWhitney. 
Table 1. Effect of the oral administration of Turnera diffusa extract (TD) on the degree and index of ulceration induced by stress by immobilization and cold on rats; on the weight of their thymus and adrenal glands and plasmatic levels of ACTH and corticosterone. Data expressed as means \pm SE.

\begin{tabular}{lcccccc}
\hline Group & degree & index & adrenal weight $(\mathrm{mg})$ & tymus weight $(\mathrm{mg})$ & ACTH $(\mathrm{pg} / \mathrm{mL})$ & corticosterone $(\mathrm{ng} / \mathrm{mL})$ \\
\hline Control & $3.9 \pm 0.4$ & $26.9 \pm 4.0$ & $12.1 \pm 0.8$ & $87.3 \pm 9.8$ & $340 \pm 43$ & $603 \pm 36$ \\
TD $200 \mathrm{mg} / \mathrm{kg}$ & $4.4 \pm 0.3$ & $25.7 \pm 3.6$ & $12.5 \pm 0.8$ & $77.5 \pm 7.7$ & $379 \pm 106$ & $625 \pm 44$ \\
TD $1000 \mathrm{mg} / \mathrm{kg}$ & $4.1 \pm 0.3$ & $23.8 \pm 3.0$ & $15.2 \pm 0.9^{*}$ & $78.3 \pm 6.4$ & $303 \pm 47$ & $685 \pm 39$ \\
\hline
\end{tabular}

${ }^{*} p<0.05$, ANOVA/Duncan.

\section{Evaluation of the in vitro antioxidant capacity}

The concentration that inhibits $50 \%\left(\mathrm{Q}_{1 / 2}\right)$ of peroxidation was $7.32 \mu \mathrm{g} / \mathrm{mL}$ (Figure 3).

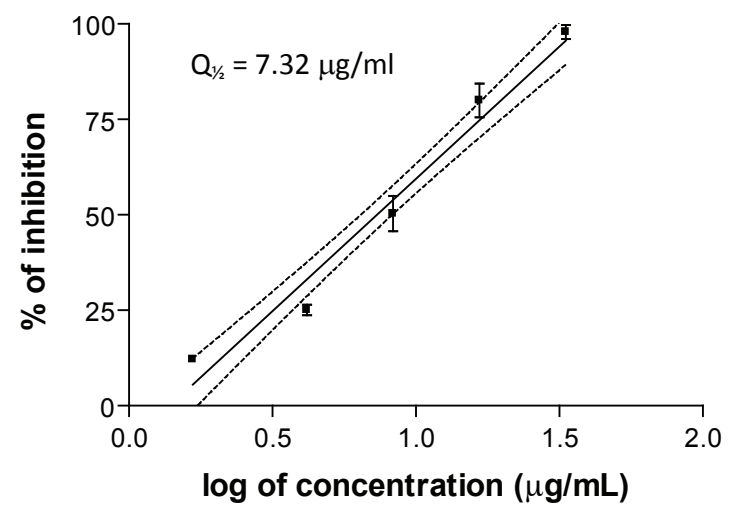

Figure 3. Inhibition of lipoperoxidation of rat brain homogenate, for the various concentrations (in $\log$ ) of the Turnera diffusa extract (TD). Each point represents the mean $\pm \mathrm{SE}$ of the concentration used. The $\mathrm{Q}^{1 / 2}$ was calculated by linear regression. The dotted lines represent the confidence interval (IC 95\%).

\section{Discussion}

The data obtained in the present study showed that the mice had good tolerability regarding the doses from 10 to $1000 \mathrm{mg} / \mathrm{kg}$ (p.o.) of the hydroalcoholic extract of TD, indicating that these doses were adequate for acute pharmacological treatment. In the evaluation of acute toxicity after high doses, no deaths were observed for the oral dose of $5 \mathrm{~g} / \mathrm{kg}$. According to Hodgson \& Levi (2000), a substance can be considered relatively safe when doses up to that one are used orally. Therefore, it is unnecessary for toxicological studies with higher doses to be carried out. We did not observe characteristic signs of stimulant or depressant effects after the oral treatment.

On the other hand, the TD intraperitoneal administration of 10 and $100 \mathrm{mg} / \mathrm{kg}$ induced abdominal contortions in the animals. This might be due to an irritant action of the extract on the peritoneum, since the extract has a $\mathrm{pH}$ of 4.5. The i.p. administration of $2 \mathrm{~g} / \mathrm{kg}$ of the extract induced six deaths out of ten animals, indicating that the LD50 of the extract administered i.p. is probably close to the lethal dose. The intraperitoneal administration was not employed on subsequent tests, since the objective of pharmacological experiments was to be as close as possible to the popular use, that is, oral administration.

The acute oral administration of TD extract to mice did not alter their locomotor activity, motor coordination or time of pentobarbital-induced sleep, suggesting the absence of neurotoxic, stimulant or depressant effects at the doses used, which corroborated the findings of the initial screening.

Even though those tests are highly unspecific, the results we obtained allowed us to carry out an initial toxicological evaluation. We might assume that the acute use of the hydroalcoholic extract of TD does not interfere in the CNS directly by depressing or stimulating it. The low toxicity presented by the oral administration of the extract would allow its chronic use, as expected from some adaptogens, used for their preventive action and the general improvement of the body they bring about (Wagner et al., 1994).

In the test of stress by immobilization and cold, a model that allows researchers to assess a possible adaptogen effect, the protocol we adopted was effective in inducing ulceration in the animals and increasing the levels of ACTH and corticosterone, when compared with the values of animals not submitted to stress employed in previous studies (Mendes et al., 2007). However, the present study did not detect statistical differences between the groups treated with the plant and those not treated. In other words, TD did not protect the animals from the formation of gastric ulcers. These results are not in line with those by Gracioso et al. (2000), who observed an inhibition of $58 \%$ in the gastric lesions of mice that received the TD hydroalcoholic extract and inhibition of $79 \%$ when the animals received dichloromethanic extract. This difference in the results might be attributed both to the model and to the extract used, since those authors induced the ulcers in mice by means of $\mathrm{HCl} /$ ethanol, and the extracts used had more polar characteristic, while the ulcers in the present study were induced in rats by stress. The immobilization and cold protocol is employed to evaluate the stress response (measured by ulceration, alteration in target tissues and hormonal levels), while in the induction of ulcer by $\mathrm{HCl} /$ ethanol protocol the focus is the chemical protection of the treatment. 
Still in the same test, the TD extract did not interfere in the weight of the thymus, but it increased the weight of the adrenal glands of the animals treated with $1000 \mathrm{mg} / \mathrm{kg}$ of the extract, while the expected result of an anti-stress drug is to inhibit the weight increase of this organ induced by repetitive stress. As regards the biochemical measurements, there were no differences in the blood doses of ACTH and corticosterone when animals treated with TD extract and the ones not treated were compared. Therefore, we can say that the stress model was effective in altering the levels of these hormones when compared with control unstressed rats from our laboratory (used in previous studies) (Mendes et al., 2007).

On the other hand, data in the literature concerning the effect of adaptogens on the hormone levels and weight of those organs are quite controversial. Some authors state that adaptogens would reduce the weight of the adrenal glands by reducing the production of stress hormones (Ramachandran et al., 1997). Others believe they have a pro-stressor effect, increasing the basal levels of hormone (and possibly the weight of organs related to that hormone) as a way of protection, since they consider the activation of the hypothalamic-pituitary-adrenal (HPA) axis as a defense mechanism of the body (Panossian et al., 1999). According to this line of thought, the increase in the weight of the adrenal glands of the animals treated with the dose of $1000 \mathrm{mg} / \mathrm{kg}$ of TD extract would lead to an increase of the correspondent hormones, which was not observed in this work. Such data indicate a probable absence of the modulation action on the HPA axis, and the protection of the gastric mucosa of the animals submitted to stress.

Another aspect that is usually enhanced by the use of adaptogens is the cognition improvement (Petkov et al., 1993; Ni et al., 1993). Some plants described as adaptogens improve the memory of animals in models of avoidance, as in the case of Panax ginseng C.A. Meyer, which prevented memory damage caused by scopolamine, in a model similar to the one in the present study (Hsieh et al., 2000); of Ptychopetalum olacoides Benth. (Da Silva et al., 2004), which improved the recovery of evoked memory of old mice; and of Evolvulus alsinoides (L.) L., which also prevented the deficit caused by scopolamine in rats (Siripurapu et al., 2005). In the present study, the administration of the hydroalcoholic extract of TD at the doses of 100 and $500 \mathrm{mg} / \mathrm{kg}$ for 43 days did not inhibit the deficit induced by scopolamine, indicating that the extract might not have a cholinergic effect.

Finally, the antioxidant property of the plant was also evaluated in this study. The TD extract presented $\mathrm{Q}_{1 / 2}$ of $7.32 \mu \mathrm{g} / \mathrm{mL}$, indicating a low activity when compared with the levels presented by "guaraná" (Paullinia cupana Kunth) and "nó-de-cachorro" (Heteropterys aphrodisiaca O. Mach), of 1.2 and $3.3 \mu \mathrm{g} / \mathrm{mL}$, respectively (Mattei et al., 1998; 2001), or with the reference substance, butyl- hydroxytoluene $\left(\mathrm{Q}_{1 / 2}\right.$ equal to $\left.0.6 \mu \mathrm{g} / \mathrm{mL}\right)$ (Mattei et al., 2001).

In conclusion, the results obtained in this work suggest that the hydroalcoholic extract of TD has low toxicity, with no evidence whatsoever of an effect on memory and as anti-stress. Even so, further studies are necessary, with other methodologies and different types of extract, to evaluate the possible effects alleged by the population.

\section{Acknowledgements}

The authors are grateful to biologist Cristiano Rodrigo Resende for his help with the experiments. The authors would also like to thank Fapesp, Cebrid and Afip for the financial support.

\section{References}

Alarcon-Aguilar FJ, Roman-Ramos R, Flores-Saens JL, AguirreGarcia F 2002. Investigation on the hypoglycaemic effects of extracts of four Mexican medicinal plants in normal and alloxan-diabetic mice. Phytother Res 16: 383-386

Alarcon-Aguilar FJ, Roman-Ramos R, Perez-Gutierrez S, Aguilar-Contreras A, Contreras-Weber CC, Flores-Saens JL 1998. Study of the anti-hyperglycemic effect of plants used as antidiabetics. $J$ Ethnopharmacol 61: 101-110.

Arbo MM 2010. Turneraceae in Lista de Espécies da Flora do Brasil. Jardim Botânico do Rio de Janeiro. http:// floradobrasil.jbrj.gov.br, acess in november 2010.

Arletti R, Benelli A, Cavazzuti E, Scarpetta G, Bertolini A 1999. Stimulating property of Turnera diffusa and Pfaffia paniculata extracts on the sexual behavior of male rats. Psychopharmacology 143: 15-19.

Carlini EA, Contar JDP, Silva-Filho AR, Silveira-Filho NG, Frochtengarden ML, Bueno OFA 1986. Pharmacology of lemongrass (Cymbopogon citratus Stapf). I. Effects of teas prepared from the leaves on laboratory animals. $J$ Ethnopharmacol 17: 37-64.

Carlini EA, Rodrigues E, Mendes FR, Tabach R, Gianfratti B 2006. Treatment of drug dependence with Brazilian herbal medicines. Braz J Pharmacogn 16(supl): 690695.

Corrêa MP 1984. Dicionário das Plantas Úteis do Brasil e das Exóticas Cultivadas. 6 Volumes. Ministério da Agricultura/Instituto Brasileiro de Desenvolvimento Florestal: Brasília.

Da Silva AL, Piato ALS, Bardini S, Netto CA, Nunes DS, Elisabetsky E 2004. Memory retrieval improvement by Ptychopetalum olacoides in young and aging mice. $J$ Ethnopharmacol 95: 199-203.

Estrada-Reyes R, Ortiz-López P, Gutiérrez-Ortíz J, MartinezMota L 2009. Turnera diffusa Wild (Turneraceae) recovers sexual behavior in sexually exhausted males. $J$ 
Ethnopharmacol 123: 423-429.

Franco SL 1990. Maytenus ilicifolia Martius ex. Reiss. Celestraceae - Proposta tecnológica de macerados. Porto Alegre. Dissertação de mestrado - Universidade Federal do Rio Grande do Sul.

Gracioso JS, Vilegas W, Batochio M, Nasser LM, Camargo EES, Hiruma-Lima CA, et al 2000. Preliminary antiulcerogenic activity of three organics extracts obtained from Turnera diffusa L. and Turnera ulmifolia L. XVI Congresso Latino-Americano de Farmacologia. Águas de Lindóia, Brasil.

Hodgson E, Levi PE 2000. A Textbook of Modern Toxicology. $2^{\text {nd }}$ ed. New York: McGraw.

Hsieh M, Peng W, Wu C, Wang W 2000. The ameliorating effects of the cognitive-enhancing Chinese herbs on scopolamine-induced amnesia in rats. Phytother Res 14: 375-377.

Kumar S, Sharma A 2006. Apigenin: the anxiolytic constituent of various extracts of Turnera aphrodisiaca. Pharm Biol 44: 84-90.

Kumar S, Sharma A 2005. Anti-anxiety activity studies of various extracts of Turnera aphrodisiaca Ward. J Herb Pharmacother 5: 13-21

Marques LC, Galvão SMP, Espínola E, Dias RF, Mattei R, Oliveira MGM, Carlini EAC 2004. Psychopharmacological assessment of Pfaffia glomerata roots (extract BNT-08) in rodents. Phytother Res 18: 566-572.

Mattei R, Barros MP, Galvão SMP, Bechara EJH, Carlini EA 2001. Heteropteris aphrodisiaca O. Machado: effects of extract BST 0298 on the oxidative stress of young and old rat brains. Phytother Res 15: 604-607.

Mattei R, Dias RF, Espínola EB, Carlini EA, Barros SBM 1998. Guarana (Paullinia cupana): toxic behavioral effects in laboratory animals and antioxidant activity in vitro. $J$ Ethnopharmacol 60: 111-6.

Mendes FR, Mattei R, Carlini EA 2002. Activity of Hypericum brasiliense and Hypericum cordatum on the central nervous system in rodents. Fitoterapia 73: 462-471.

Mendes FR, Carlini EA 2007. Brazilian plants as possible adaptogens: an ethnopharmacological survey of books edited in Brazil. J Ethnopharmacol 109: 493-500.

Mendes FR, Tabach R, Carlini EA 2007. Evaluation of Baccharis trimera and Davilla rugosa in tests for adaptogen activity. Phytother Res 21: 517-522.

Miller RA 1993. The magical and ritual use of aphrodisiacs. Rochester, Vermont: Destiny Books, p.15-20.

Mors WB, Rizzini CT, Pereira NA 2000. Medicinal Plants of Brazil. Algonac: Reference Publications, Inc., p. 327328.

Ni XH, Ohta H, Watanabe H, Matsumoto K 1993. Panax ginseng extract improves scopolamine-induced deficits in working memory performance in the T-maze delayed alternation task in rats. Phytother Res 7: 49-52.

Palma BD, Suchecki D, Tufik S 2000. Differential effects of acute cold and footshock on the sleep of rats. Brain Res
861: 97-104.

Panossian A, Wikman G, Wagner H 1999. Plant adaptogens. III. Earlier and more recent aspects and concepts on their mode of action. Phytomedicine 6: 287-300.

Petkov VD, Kehayov R, Belcheva S, Konstantinova E, Petkov VV, Getova D, et al 1993. Memory effects of standardized extracts of Panax ginseng (G115), Ginkgo biloba (GK 501) and their Combination Gincosan (PHL-00701). Planta Med 59: 106-114.

Pires JM, Mendes FR, Negri G, Duarte-Almeida JM, Carlini EA 2009. Antinociceptive peripheral effect of Achillea millefolium L. and Artemisia vulgaris L.: both plants known popularly by brand names of analgesic drugs. Phytother Res 23: 212-219.

Ramachandran J, Raos AJ, Liles S 1997. Studies of the trophic action of ACTH. Ann N Y Acad Sci 297: 336-48.

Russo E 2001. Handbook of psychotropic herbs - A scientific analysis of herbal remedies for psychiatric conditions. New York: The Haworth Press.

Siripurapu KB, Gupta P, Bhatia AG, Maurya R, Nath C, Palit $\mathrm{G}$ 2005. Adaptogenic and anti-amnesic properties of Evolvulus alsinoides in rodents. Pharmacol Biochem Behav 81: 424-432.

Stocks J, Gutteridge MC, Sharp RJ, Dormandy TL 1974. Assay using brain homogenate for measuring the antioxidant activity of biological fluids. Clin Sci Mol Med 47: 215222.

Tropicos.org 2010 Missouri Botanical Garden. http://www. tropicos.org/Name/33100134, acess in november 2010.

Wagner H, Nörr H, Winterhoff H 1994. Plant adaptogens. Phytomedicine 1: 63-67.

\section{*Correspondence}

Fúlvio R. Mendes

Universidade Federal do ABC, Rua Santa Adélia, 166, 09210-

170 Santo André-SP, Brazil

fulvio@psicobio.epm.br

Tel. +55 1121490161

Fax: +55 1150842793 